\title{
Calanoida (Crustacea Copepoda) from the inland waters of Apulia (south-eastern Italy)
}

\author{
Giuseppe ALFONSO* and Genuario BELMONTE \\ Laboratory of Zoogeography and Fauna, Department of Biological and Environmental Sciences and Technologies (Di.S.Te.B.A.), \\ University of Salento, I-73100 Lecce, Italy \\ *e-mail corresponding author: giuseppe.alfonso@unisalento.it
}

\begin{abstract}
The currently available knowledge on biodiversity and species distribution of Italian fauna still presents some gaps to be filled, in particular in the southern part of the country. This study represents the first survey aimed at assessing the presence and distribution of Calanoida in inland waters of Apulia (south-eastern Italy). The research lasted five years and led to the mapping of 121 inland water bodies, most of which are characterized by temporary hydroperiods. Fifty-five of the sampled sites hosted at least one calanoid species, and 48 sites (among the 55 sites hosting Calanoida) are temporary water bodies. Thirteen calanoid species were detected in total; several of these are first records for Apulia and three species are new records for mainland Italy. The efficiency of the sampling effort was tested for both the entire Apulian territory and its main subareas, namely Gargano (in northern Apulia), and Salento (southern Apulia). Central Apulia showed the lowest species richness among the three sampled subareas. This is probably due to the scarcity of inland water bodies. Species composition of Apulian calanoid fauna was compared to the ones of the geographically close areas for which data are available: the other Italian faunal provinces (Alpine, Apennine, Padanian, Sardinian and Sicilian provinces) and the Balkans (Albania, Corfu, Croatia, Greece and Turkish Trace, Macedonia, Slovenia). Gargano and Salento showed a different assemblage of vicariant species but both the areas showed a remarkable presence of Mediterranean elements that, in fact, characterize the whole Apulian faunal province. The highest similarities for inland water calanoid fauna, which were observed between Gargano and the Apennine province, and between Salento and Sicily, are discussed, along with the total assessment of the whole Apulian calanoid fauna.
\end{abstract}

Key words: Copepoda, Calanoida, Apulia, inland waters, biogeography, Italian fauna

\section{INTRODUCTION}

Calanoida (Crustacea, Maxillopoda) is an order of Copepoda which has colonized almost every kind of aquatic environment (Boxshall \& Halsey 2004). Excluding the species inhabiting the water bodies directly connected to the sea, at present the calanoid fauna of Italian inland waters include 28 species belonging to 4 families (25 Diaptomidae, 1 Temoridae, 1 Pseudodiaptomidae, and 1 Centropagidae: Stoch 2006a). Nevertheless the Italian territory has not been exhaustively covered by research on this crustacean group, especially in the southern part of the country (Belmonte et al. 2006; Marrone 2006).

Apulia is the south-easternmost area of the Italian peninsula. From a biogeographical perspective, the Apulian province has been proposed as one of the six Italian faunal provinces (Minelli et al. 2006). Stoch (2006b) specified, in detail, two different sectors for the Apulian province, the northern and the southern one (or Salento sector), both characterized by a large number of Mediterranean species. The central part of the Apulian province (the area including the hilly area called Murge), on the other hand, appears to be more characterized by European elements with a northern gravitation rather than by Mediterranean ones, thus repre- senting a faunal hiatus between northern and southern Apulia (Stoch 2006b).

All these considerations were based mainly on the invertebrates listed in the most updated checklist of Italian fauna (Ruffo \& Stoch 2006), according to which Apulia counts only one calanoid species, the pseudodiaptomid Calanipeda aquaedulcis, reported by Cannicci (1939) for the coastal lagoon of Lesina (in northern Apulia) and by Cavallo \& Belmonte (1995) for the 'Le Cesine' wetlands (in southern Apulia). Two recent papers (Alfonso \& Belmonte 2008; Scirocco et al. 2008) updated the checklist of Calanoida for Apulia. The following species have been included: Arctodiaptomus wierzejskii, Diaptomus cyaneus, Hemidiaptomus gurneyi for the Gargano National Park (northern Apulia) (Scirocco et al. 2008) and Boeckella triarticulata for a reservoir in central Apulia (Alfonso \& Belmonte 2008). A recent study on the genus Hemidiaptomus included some Apulian populations of Hemidiaptomus gurneyi and $H$. ingens that were collected within the frame of the present survey (Marrone et al. 2010). Nevertheless, to date, no study has been addressed to the entire Apulian territory and to a biogeographical analysis of the Apulian Calanoida. As a consequence, the aims of the present paper are: i) to carry out a census of Calanoida in the inland waters of the whole Apulian faunal province sensu Minelli et al. (2006); ii) to clarify 


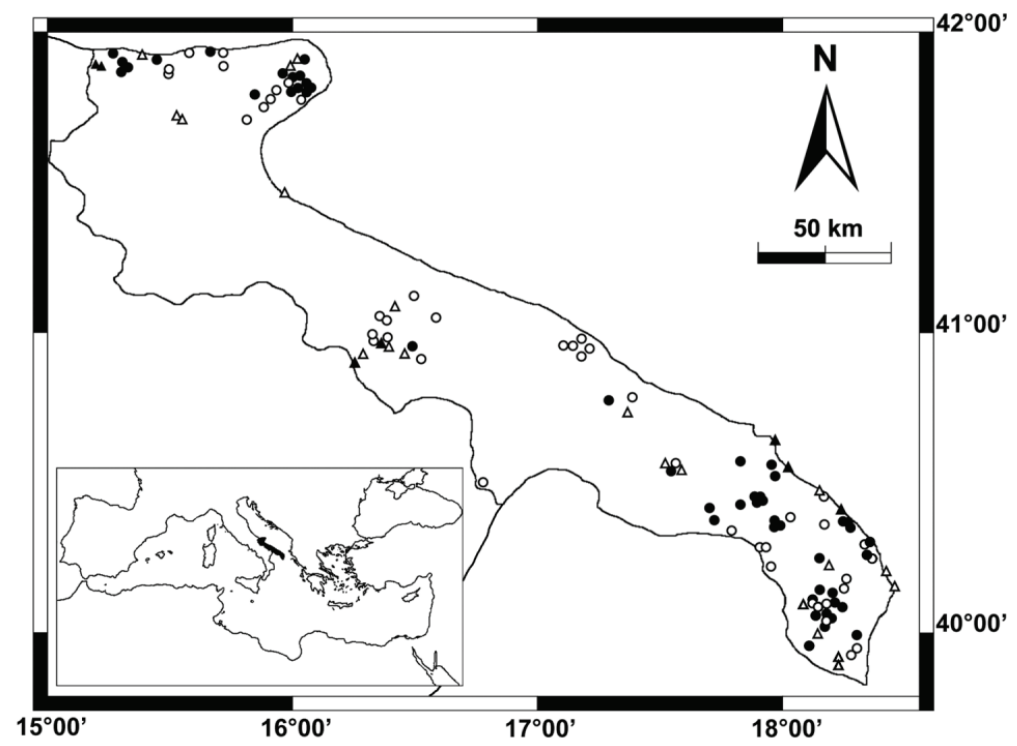

Fig. 1. Map of Apulia with sampling sites. Triangles represent permanent water bodies, circles temporary ones. Full symbols represent sites hosting at least one species of Calanoida, empty symbols represent environments without Calanoida.

the distribution of collected species; iii) to analyze the biogeographical setting of the Apulian province based on its calanoid species.

\section{METHODS}

\subsection{Study area}

Apulia is the south-easternmost area of the Italian peninsula, stretching out towards the Balkans, which are just about 75 kilometres away; this linear distance lies along the conventional boundary between the Adriatic and Ionian Sea. With a surface area of $19,357 \mathrm{~km}^{2}$, Apulia is mostly characterised by an arid karst platform in its southern part, a succession of broad plains and low hills in the centre, and reaches its highest altitudes in the Gargano Promontory and Dauni Mountains in the northern part of the region, although never exceeding 1150 meters a.s.l. (ISTAT 2004). As a consequence, Apulia is the least mountainous region in Italy, and its hydrographical surface network is poorly developed. The Apulian climate is typically Mediterranean (Macchia et al. 2000) with scarce rainfall, mainly concentrated in late autumn and winter, with average annual rainfall values generally ranging between 500 and $750 \mathrm{~mm}$ (Zito et al. 1991).

Three Apulian subareas were considered to obtain the most detailed characterization possible of the Apulian calanoid fauna. These subareas are: Gargano (the promontory in the northern Apulia), central Apulia, and Salento (the peninsula corresponding to the southern Apulia) (Fig. 1).

\subsection{Sample collection and analysis}

The survey was carried out from 2005 to 2010 , and involved a total of 121 inland water bodies, including both temporary and permanent waters, from the sea level up to $804 \mathrm{~m}$ a.s.l. All the sites were sampled in the autumn-winter period, which corresponds to the ponding phase of the temporary waters in the Mediterranean area.

Zooplankton samples were collected by towing a zooplankton net ( $24 \mathrm{~cm}$ mouth, $125 \mu \mathrm{m}$ mesh size) horizontally, as the depth of most sampled sites generally did not exceed $1 \mathrm{~m}$. Samples were fixed in situ with buffered $(\mathrm{pH}$ 7.3) formalin at a final concentration of $4 \%$, or with ethanol $96 \%$. Altitude (m a.s.l.) and geographical coordinates were recorded by a mobile GPS Garmin ${ }^{\circledR} 12$ in each site. The habitat typology of each water-body was also recorded, specifying whether its hydroperiod was permanent or temporary.

In the laboratory, samples were analysed in order to sort and identify calanoid species with a Zeiss Axiovert inverted microscope. Species were identified according to Bayly (1992), Dussart $(1967 ; 1989)$, Dussart \& Defaye (2001), Einsle (1993), Kiefer (1978), Petkovski (1983), Ranga Reddy (1994), Stella (1984). The chorotype for each species was defined following Vigna Taglianti et al. (1992) and Dussart \& Defaye (2002).

\subsection{Statistical analysis}

EstimateS v.8.2.0 computer program (Colwell 2009) was used for computing rarefaction curves and to evaluate whether the sampling effort in Apulia could be considered exhaustive and representative of the actual calanoid fauna of the region. The subareas Gargano and Salento were also considered separately for the analysis with EstimateS; the central subarea was not included in the analysis because of the extremely low numbers of sampled sites and species. The species richness estimators Bootstrap, Chao 2 and Michaelis Menten were calculated. The rarefaction curve was represented by the 
Tab. 1. Frequency of Calanoida in Apulia (calculated as percentage of sites with Calanoida in each subarea over the total number of sites sampled) and in its sub-areas (calculated as percentage of sites with Calanoida in each subarea over the total number of sites sampled in the same area) $(\mathrm{T}=$ temporary sites; $\mathrm{P}=$ permanent sites $)$.

\begin{tabular}{lccccccccc}
\hline & \multicolumn{3}{c}{ Samples sites } & & \multicolumn{3}{c}{ Sites with Calanoida } & Freq. in each area \\
\cline { 2 - 3 } & Total & $\mathrm{T}$ & $\mathrm{P}$ & & Total & $\mathrm{T}$ & $\mathrm{P}$ & $\begin{array}{c}\text { Feq. in Apulia } \\
(\%)\end{array}$ \\
\hline Gargano & 35 & 26 & 9 & & 18 & 15 & 3 & 51.43 & 14.87 \\
Centre & 24 & 17 & 7 & & 4 & 2 & 2 & 16.66 & 3.30 \\
Salento & 62 & 50 & 12 & & 33 & 31 & 2 & 53.22 & 27.27 \\
APULIA & 121 & 93 & 28 & & 55 & 48 & 7 & & \\
\hline
\end{tabular}

Sobs (Mao Tau) curve (Colwell 2009). Based on presence/absence data of species, the mean values of uniques (i.e. species present only in a single sample) and duplicates (i.e. species present in exactly two samples), were also calculated using EstimateS program both for the entire Apulia and for its subareas.

Only the temporary water-bodies, the most widespread water-bodies in Apulia, were selected for the multivariate analysis. Permanent water-bodies were excluded from this analysis because they proved to host very rare species in Apulia, thus representing very marginal conditions for the region. Primer v6 computer program (Clarke \& Gorley 2006) was used for computing the nMDS (non metric Multi Dimensional Scaling) plots on temporary sites hosting Calanoida (based on BrayCurtis similarity matrix of presence/absence data of species) according to their location in Apulia (Gargano, central Apulia, Salento). A cluster analysis (using the 'group average' as cluster mode) was also performed on the Bray-Curtis similarity resemblance matrix of presence/absence data of calanoid fauna of the Apulian subareas (data from this study) and on available data of the geographically close areas, namely the other Italian faunal provinces (Stoch 2006a; Marrone 2006) and the Balkan countries as Albania (Dussart \& Defaye 2002; Shehu et al. 2010), Corfu (Marrone 2006), Croatia (Ternjej \& Stanković 2007), Greece and Turkish Trace (Güher \& Kirgiz 2004; Marrone 2006), Macedonia (Petkovski 1983), Slovenia (Brancelj 1996).

\section{RESULTS}

\subsection{Species richness and distribution}

Ninety-three of the 121 sampled sites (Fig. 1 and Annex) were characterised by temporary hydroperiods (76.8\% of the total), whereas 28 out of 121 were permanent waters $(23.1 \%)$. Calanoida were present in 55 sites $(45.5 \%$ of all sampled sites), 48 of which were temporary (51.6\% of all sampled temporary sites) and 7 were permanent ( $25 \%$ of all sampled permanent sites). Frequencies of occurrences of Calanoida in the subareas, and details on the typology of sites for each subarea are shown in table 1 . The frequency of sites hosting Calanoida is higher in Salento than in each subarea considered separately (53.2\%) and in the whole of Apulia $(27.3 \%)$.

On the whole, 13 calanoid species were recorded (Tab. 2). They belong to three different families: Cen- tropagidae (1 species), Diaptomidae (11 species), Pseudodiaptomidae (1 species). Eight species were exclusive to temporary water bodies, four species were exclusive to permanent ones and one species (Eudiaptomus vulgaris) was detected in both kinds of habitat. Arctodiaptomus wierzejskii was the most common species in Apulia (18 sites) followed by Mixodiaptomus kupelwieseri (16 sites). These species were always collected in sites with a temporary hydroperiod. The rarest species were Calanipeda aquaedulcis (2 sites), Arctodiaptomus salinus (1 site), Boeckella triarticulata (1 site), and Copidodiaptomus steueri (1 site), which were detected in different typologies of permanent waters (two coastal lagoons, a retrodunal pond, a reservoir, and a small agricultural pond, respectively). In table 2 we attributed each calanoid species detected in Apulia to a chorotype (sensu Vigna Taglianti et al. 1992). Eight different chorotypes were identified; Mediterranean species dominate the biogeographic scenario of Apulia, followed by Palearctic and European elements.

Figure 2 shows the distribution maps of the inland water Calanoida in Apulia. The subarea Salento showed the highest species richness (9) when compared to the other Apulian subareas. Six species were recorded in Gargano, four of which are in common with Salento. Central Apulia was the subarea with the lowest number of species (3).

Arctodiaptomus wierzejskii is the only species present in all three subareas. Arctodiaptomus salinus, Diaptomus cyaneus, Hemidiaptomus ingens, Mixodiaptomus incrassatus and M. kupelwieseri were recorded only in Salento, Boeckella triarticulata and Copidodiaptomus steueri were found exclusively in Central Apulia, Eudiaptomus vulgaris and Mixodiaptomus lilljeborgi were exclusive to Gargano.

\subsection{Rarefaction curves and species richness estimation}

Rarefaction and estimation curves applied to the whole Apulian territory are shown in figure 3A. The rarefaction curve appears to be close to the plateau at 13 species. MM Means and Chao 2 estimates indicate a plateau of 15 species, Bootstrap estimate is just a little above 14 species. For all 121 sites, uniques (species present only in a single site) and duplicates (species present in exactly two sites) means tend to stabilize their trends respectively with 1 species and 3 species (Fig. 3B). 
Tab. 2. List of Calanoida collected in the Apulian inland waters and sampling sites. Chorotypes refer to Dussart \& Defaye (2002), modified considering the updated distribution data. Codes of chorotypes follow Vigna Taglianti et al. (1992): ASE = Asiatic European; MED = Mediterranean; PAL = Palaearctic; SEU = South European; TUE = Turanic European; TUM = Turanic Mediterranean; WME = Western Mediterranean. NIS = non indigenous species.

\begin{tabular}{|c|c|c|}
\hline & SITE CODE & CHOROTYPE \\
\hline \multicolumn{3}{|l|}{$\begin{array}{l}\text { Family CENTROPAGIDAE Giesbrecht, } 1892 \\
\text { Genus Boeckella De Guerne \& Richard, } 1889\end{array}$} \\
\hline \multicolumn{3}{|l|}{$\begin{array}{l}\text { Family DIAPTOMIDAE G.O. Sars, } 1903 \\
\text { Subfamily DIAPTOMINAE Kiefer, } 1932\end{array}$} \\
\hline \multicolumn{3}{|l|}{$\begin{array}{l}\text { Genus Arctodiaptomus Kiefer, } 1932 \\
\text { Subgenus Arctodiaptomus Kiefer, } 1932 \\
\text { Arctodiaptomus (Arctodiaptomus) wierzejskii (Richard, 1888) }\end{array}$} \\
\hline $\begin{array}{l}\text { Subgenus Rhabdodiaptomus Kiefer, } 1932 \\
\text { Arctodiaptomus (Rhabdodiaptomus) salinus (Daday, 1885) }\end{array}$ & PU021 & PAL \\
\hline $\begin{array}{l}\text { Genus Copidodiaptomus Kiefer, } 1968 \\
\text { Copidodiaptomus steueri (Brehm, 1904) }\end{array}$ & PU052 & Apennine-Dinaric \\
\hline $\begin{array}{l}\text { Genus Diaptomus Westwood, } 1836 \\
\text { Subgenus Chaetodiaptomus Kiefer, } 1978 \\
\text { Diaptomus (Chaetodiaptomus) cyaneus Gurney, } 1909\end{array}$ & $\begin{array}{l}\text { PU001 PU002 PU003 } \\
\text { PU007 PU010 PU013 } \\
\text { PU014 PU059 }\end{array}$ & MED \\
\hline Diaptomus (Chaetodiaptomus) serbicus Gjorgjevič,1907 & $\begin{array}{l}\text { PU011 PU015 PU026 } \\
\text { PU071 }\end{array}$ & TUE \\
\hline $\begin{array}{l}\text { Genus Eudiaptomus Kiefer, } 1932 \\
\text { Eudiaptomus vulgaris (Schmeil, 1898) }\end{array}$ & $\begin{array}{l}\text { PU081 PU085 PU086 } \\
\text { PU092 PU093 }\end{array}$ & ASE \\
\hline $\begin{array}{l}\text { Genus Hemidiaptomus G.O. Sars, } 1903 \\
\text { Subgenus Hemidiaptomus G.O. Sars, } 1903 \\
\quad \text { Hemidiaptomus (Hemidiaptomus) gurneyi (Roy, 1927) }\end{array}$ & $\begin{array}{l}\text { PU015 PU030 PU031 } \\
\text { PU032 PU071 PU077 } \\
\text { PU086 }\end{array}$ & MED \\
\hline $\begin{array}{l}\text { Subgenus Occidodiaptomus Borutzky, } 1991 \\
\text { Hemidiaptomus (Occidodiaptomus) ingens (Gurney, 1909) }\end{array}$ & $\begin{array}{l}\text { PU001 PU002 PU003 } \\
\text { PU004 PU018 PU020 } \\
\text { PU100 PU104 }\end{array}$ & WME \\
\hline $\begin{array}{l}\text { Genus Mixodiaptomus Kiefer, } 1932 \\
\text { Mixodiaptomus incrassatus (G.O. Sars, 1903) }\end{array}$ & $\begin{array}{l}\text { PU007 PU013 PU014 } \\
\text { PU024 }\end{array}$ & PAL \\
\hline Mixodiaptomus kupelwieseri (Brehm, 1907) & $\begin{array}{l}\text { PU020 PU049 PU050 } \\
\text { PU075 PU076 PU077 } \\
\text { PU098 PU100 PU102 } \\
\text { PU103 PU104 PU105 } \\
\text { PU110 PU112 PU114 } \\
\text { PU117 }\end{array}$ & SEU \\
\hline Mixodiaptomus lilljeborgi (Guerne \& Richard, 1888) & $\begin{array}{l}\text { PU026 PU031 PU032 } \\
\text { PU033 PU067 PU072 } \\
\text { PU082 PU085 PU086 } \\
\text { PU087 }\end{array}$ & MED \\
\hline $\begin{array}{l}\text { Family PSEUDODIAPTOMIDAE G.O. Sars, } 1903 \\
\text { Genus Calanipeda Kritshagin, } 1873 \\
\text { Calanipeda aquaedulcis Kritshagin, } 1873\end{array}$ & PU023 PU089 & TUM \\
\hline
\end{tabular}



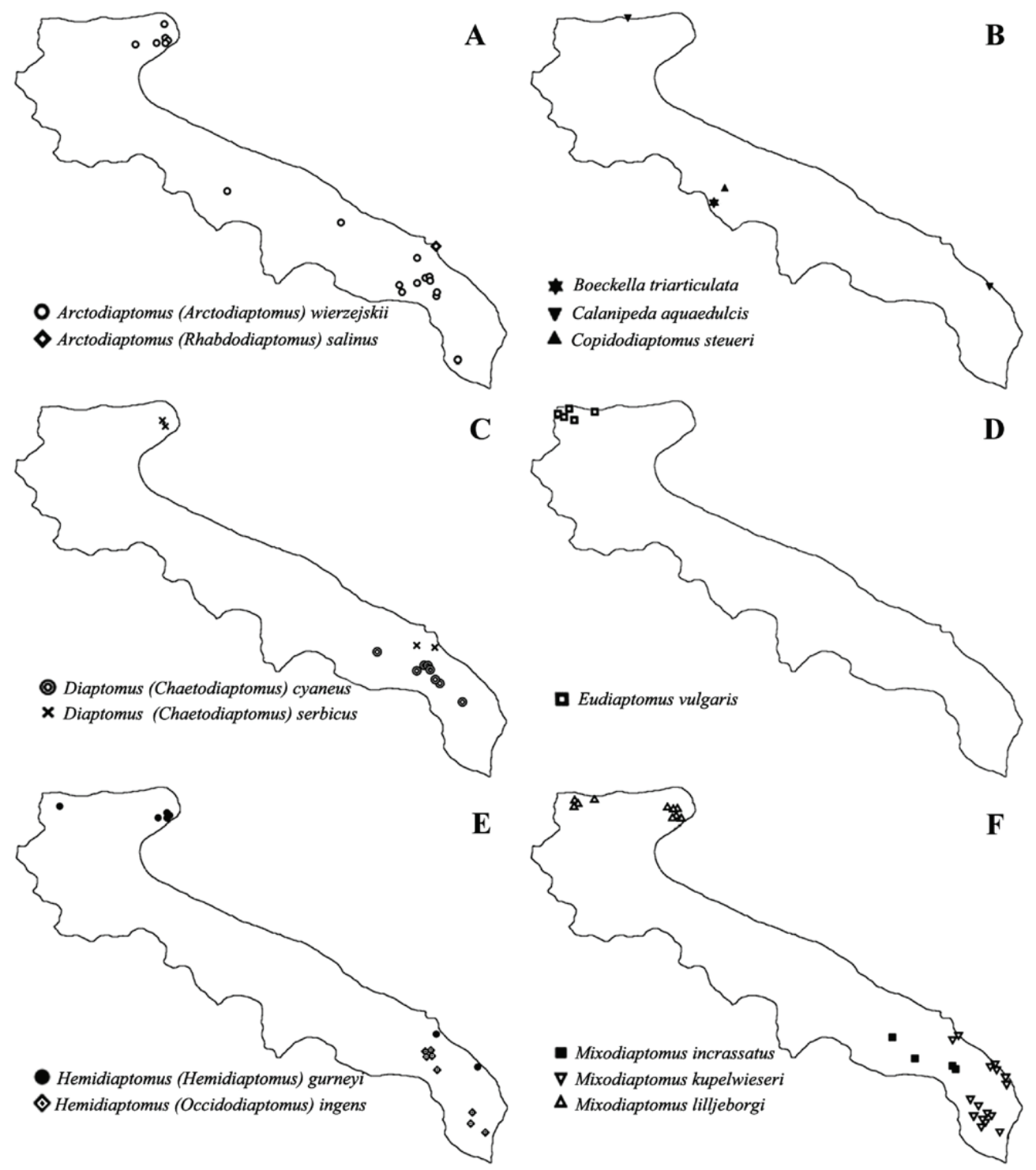

Fig. 2. Distribution maps of inland water Calanoida in Apulia.

Considering Gargano and Salento subareas separately, different values were detected. In the first case (Fig. 3C), the rarefaction curve indicates a plateau of 6 species, the same value reached by the Chao 2 estimator. MM Means and Bootstrap estimators have their plateau just above and just below 7 species respectively. Both uniques and duplicates stabilized at one species when sampling size was 35 sites or higher (Fig. 3D). The subarea Salento (Fig. 3E) shows the plateau of the rarefaction curve at 9 species, and also Chao 2 estimator appears to reach the same value. MM Means and Bootstrap tend to a plateau at 10 species. Uniques and duplicates means both converge to 2 species at 62 sites (Fig. 3F).

\subsection{Results of the multivariate statistical analysis}

The nMDS analysis of the temporary water bodies (Fig. 4), derived from the presence/absence matrix, showed a group including sites belonging to the
Gargano subarea mostly separated from the Salento group. Two very dense clouds of points are visible on the plot. One, on the lower right of the plot, includes all sites of Salento hosting Mixodiaptomus kupelwieseri as single calanoid species per site. The other dense cloud of points, instead, at the top at the centre of the plot, includes all sites of Gargano with Mixodiaptomus lilljeborgi as single calanoid species per site. The only two points referring to central Apulia temporary waters with Calanoida, i.e. Arctodiaptomus wierzejskii only, are located in the centre of the plot, together with points referring to the Gargano and Salento sites where the same species was detected living alone. Most of the other points on the plot represent sites (both in Gargano and Salento) where more than one calanoid species is present.

The cluster analysis (Fig. 5), based on presence/ absence data of calanoid fauna, and performed considering Gargano and Salento separately, showed Gargano grouped with the Apennine province $(61 \%$ of simila- 

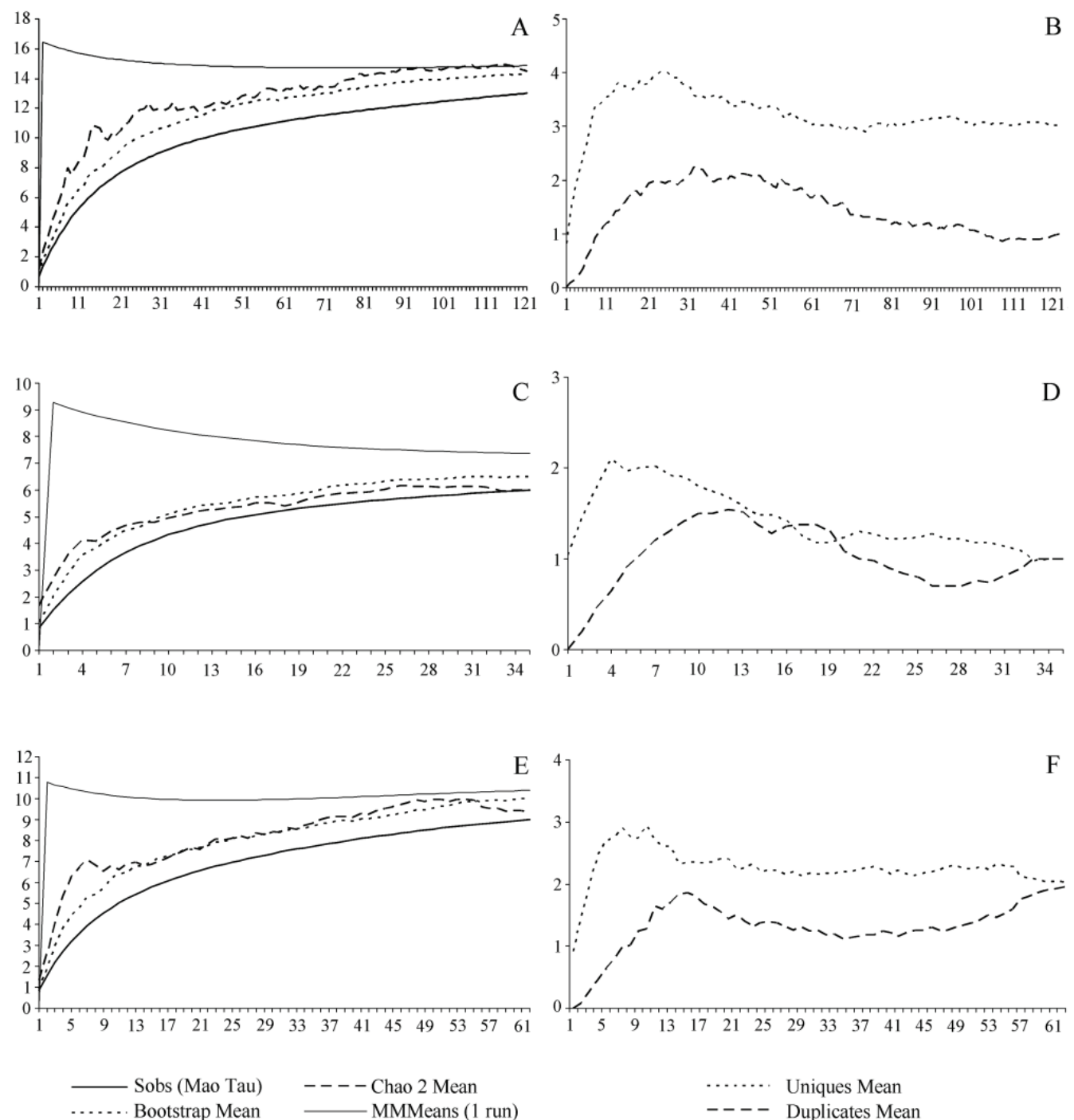

Fig. 3. A, C, E: species accumulation curves (Sobs - Mao Tau) and performance of estimators of Calanoida species richness (Bootstrap Mean, Chao 2 Mean and MMMeans -1 run) respectively for the Apulia (whole territory), Gargano, and Salento as a function of increasing sample size. B, D, F: performance of uniques (species present only in a single sample) and duplicates (species present in exactly two samples) curves respectively for Apulia (whole territory), Gargano, and Salento. Number of sampled sites are on the $\mathrm{x}$-axis, number of species are on the y-axis.

rity); the Salento subarea, instead, is grouped with Sicily ( $70 \%$ of similarity) and Corfu (about $60 \%$ of similarity). These two clusters belong to a higher-order cluster which also includes Sardinia (44\% of similarity) and which is well separated from the other Italian faunal provinces, (i.e. the Padanian and Alpine provinces). The Alpine province is the only Italian faunal province grouped with Slovenia, Croatia and Macedonia and separated from a second group including the Southern Balkan areas (Albania, Greece and Turkish Thrace).

\section{DISCUSSION}

\subsection{Species richness}

The number of inland water Calanoida detected in Apulia (13 species) as a result of the present study, is the highest, so far, for an Italian administrative region and only the second for an Italian faunal province. This high number of species is very far from what was formerly known for the area, considering that five species were reported in total, until now, as a result of the last updates (Stoch 2006a; Alfonso \& Belmonte 2008; Scirocco et al. 2008).

Arctodiaptomus salinus, Copidodiaptomus steueri, Diaptomus serbicus, Eudiaptomus vulgaris, Hemidiaptomus ingens, Mixodiaptomus lilljeborgi, M. kupelwieseri, M. incrassatus are all new records for Apulia. Three species are recorded for the first time in the Italian peninsula: A. salinus, $H$. ingens and $M$. incrassatus. The most widespread species was $A$. wierzejskii. The Apulian population of Copidodiaptomus steueri confirms the presence of this species in Southern Italy, 


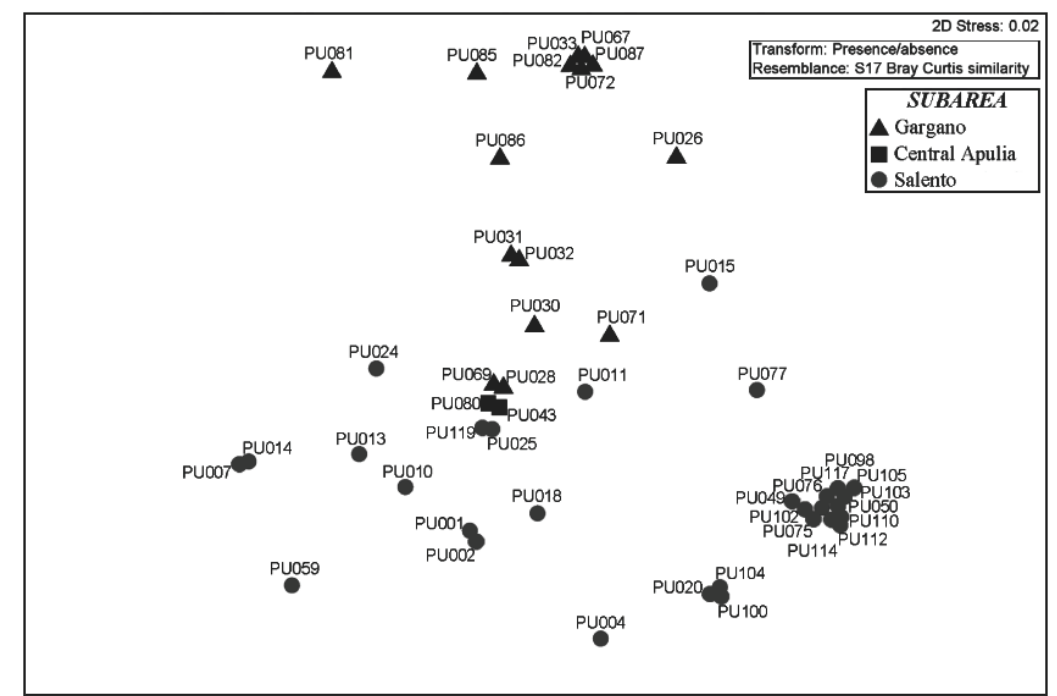

Fig. 4. The nMDS plot of the Apulian temporary waters with Calanoida. The grouping is based on the 'SUBAREA' factor.

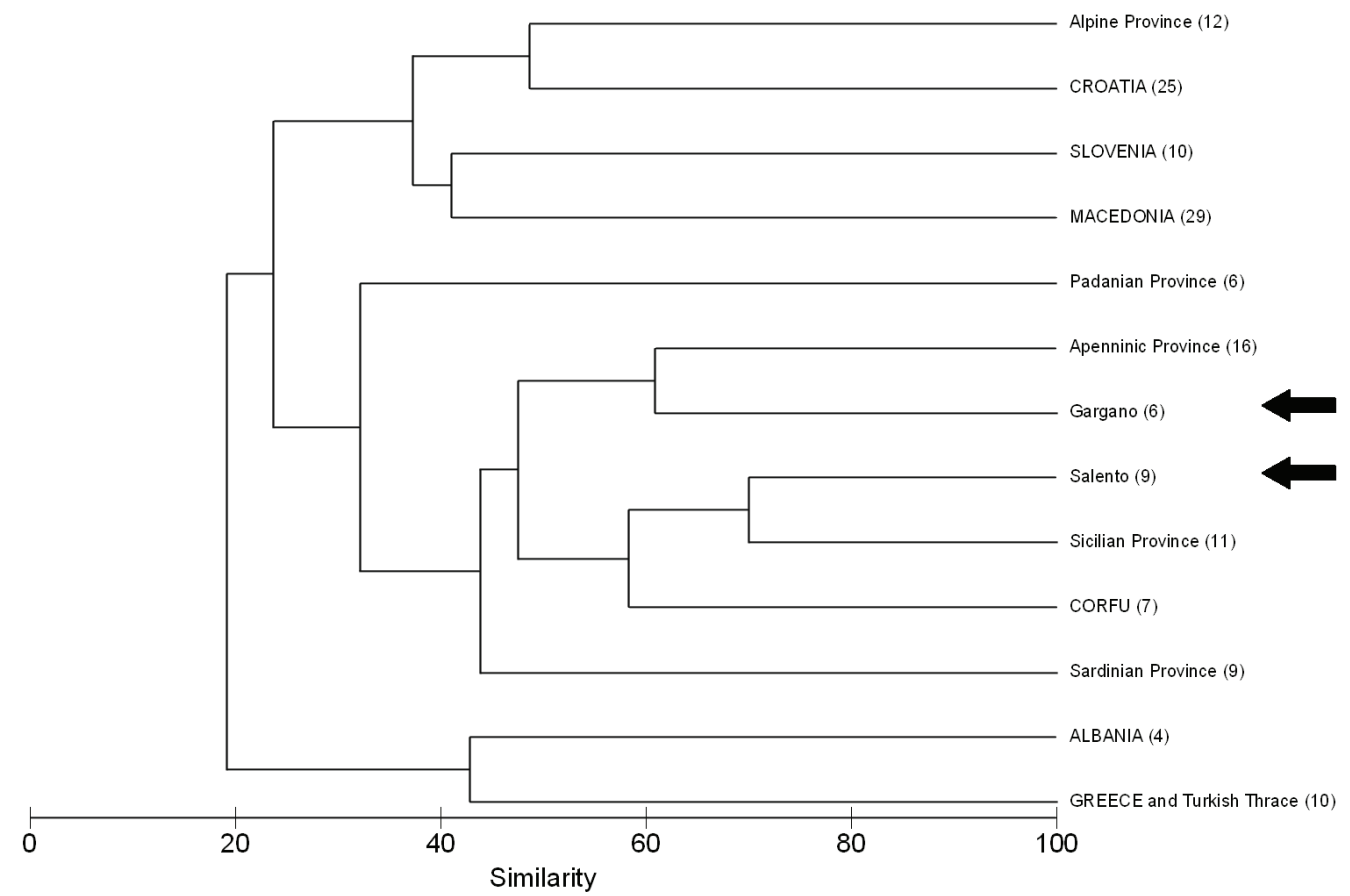

Fig. 5. Cluster analysis (group average on a Bray-Curtis resemblance matrix of presence/absence data) of the Italian faunal provinces and the Balkan areas according to their inland water Calanoida checklists. Apulian subareas (Gargano and Salento) were considered separately (see arrows). The total number of calanoid for each area is in brackets. References for each area are: Alpine, Apennine, Padanian and Sardinian provinces (Stoch 2006a); Sicilian province (Marrone 2006; Stoch 2006a); Albania (Dussart \& Defaye 2002; Shehu et al. 2010); Corfu (Marrone 2006); Croatia (Ternjej \& Stanković 2007); Gargano and Salento (this study); Greece and Turkish Trace (Güher \& Kirgiz 2004; Marrone 2006); Macedonia (Petkovski 1983); Slovenia (Brancelj 1996).

and, together with those recently reported by Alfonso et al. (2010), represents the southernmost population of its distribution area (Dussart \& Defaye 2002) defined as Apennine-Dinaric (Stoch 2006a). The colonization of Apulia by C. steueri, could have occurred very recently, since the species was detected only in an artificial agricultural pond. Since no kind of introduction took place in this site, and considering the proximity of the Apennines, it is most likely that C. steueri arrived here naturally expanding its distribution area. A similar case of recent colonization was documented for Boeckella triarticulata in the close Basentello reservoir (Alfonso \& Belmonte 2008).

Our record of Diaptomus serbicus is in contrast with the data reported by Scirocco et al. (2008), who reported $D$. cyaneus for the same sites of Gargano where we found $D$. serbicus. According to our findings (data from this study), D. cyaneus is present in Apulia only in the 
inner part of the Salento peninsula. Nevertheless further samplings are needed in order to check whether $D$. cyaneus actually occurs also in the Gargano area. Unfortunately it was not possible to check $D$. cyaneus specimens identified by Scirocco et al. (2008) because those samples had been lost (Scirocco, pers. com.).

In Italy, Hemidiaptomus ingens was first reported for two sites in western Sicily (Marrone \& NaselliFlores 2004; Marrone et al. 2010). In Apulia it was later detected (this study) in eight temporary water bodies of the Salento Peninsula, which represent the easternmost sites of the known geographic distribution area of the species. Nevertheless, based both on morphological and molecular data (Marrone et al. 2010), the Apulian population appears to be more similar to the Corsican population than to the Sicilian and Tunisian ones. It has been proposed that these morphological and molecular divergences might be correlated to some events of isolation and expansions of the species distribution during the Plio-Pleistocene period, when climate fluctuations allowed the development of local haplotypes (Marrone et al. 2010). In this scenario, the similitude of the Apulian population of $H$. ingens to the Corsican one, rather than to the Sicilian and North-African populations, could be due to stochastic dispersal events, and not ascribable to ancient paleogeographical events. Apulia, in fact, has a paleogeographical history linked to the Aegeid area (Ricchetti et al. 1988; Doglioni et al. 1996), conversely Corsica (together with Sardinia and part of Sicily) originates from the fragmentation of the paleocontinent Tyrrhenis (Mattei et al. 1996; Meulenkamp \& Sissingh 2003).

In Apulia, the genus Mixodiaptomus is represented by three species. The distribution map of species supplied (Fig. 2) shows the well-separated distribution areas of each species, with $M$. lilljeborgi occurring only in Gargano, M. incrassatus in the inner territory of Salento, and M. kupelwieseri widespread in south-eastern Salento. A somewhat similar separated distribution of the same species, in a well defined geographic area, is detectable in Sardinia (Stoch 2006a). The fine separation of the three Mixodiaptomus species in Apulia, testifies to the very close ecological requirements of these congeneric species (Kiefer 1978), which are able to survive in temporary waters thanks to the production of resting eggs, but are never coexisting in the same sites. In Apulia this fine distribution is a characteristic showed also by other vicariant species, such as Diaptomus serbicus/Diaptomus cyaneus and Hemidiaptomus ingens/Hemidiaptomus gurneyi, as already evidenced by other authors (Gauthier 1928; Kiefer 1978).

The total number of Calanoida in Apulia (13 species) is comparable, even if slightly higher, to that of the close Mediterranean areas with a similar surface and/or climate. Marrone (2006) supplies exhaustive data for inland water calanoid fauna of Corfu (7 species), Greece (6 species), Sicily (11 species), Sardinia (9 species) and
Tunisia (11 species); Jaume, (1989-1990) documented 7 calanoid species in the inland waters of the Balearic Islands; Dussart (1989) listed 15 species in all the Mediterranean area of northern Africa; Alonso (1998) listed 13 species in all the Mediterranean area of peninsular Spain.

\subsection{Efficiency of sampling effort}

The EstimateS curves for Apulia suggest that the area has been exhaustively explored and that a maximum of two additional species for the whole Apulian territory could be detected. Even considering the estimators separately for the Gargano and Salento subareas, we can state that the sampling effort gave a satisfactory result: in fact at most one species per area could have been missed in our sampling, in accordance with what was found for all the Apulian territory. It was not possible to compute the EstimateS curves for central Apulia, because of the low number of sampled sites hosting Calanoida. The low number of Calanoida in central Apulia mirrors the low number of inland waters present in this subarea, recognized as one of the so-called 'coldspots' for biodiversity in Italy (Stoch 2006b). It is also emblematic that the only non indigenous species detected (Boeckella triarticulata) was found in central Apulia. This species, however, has been suspected to be an opportunistic species which easily colonizes newly-formed sites, such as the most recent dam reservoirs (Alfonso \& Belmonte 2008). The same area is inhabited by the most common species in Apulia (Arctodiaptomus wierzejskii), and the Apennine-Dinaric species Copidodiaptomus steueri that is very close to its formerly known distribution area here.

Although the EstimateS curves referring to the whole Apulian area revealed an adequate sampling effort to describe the actual Apulian calanoid fauna, some subareas still remain nearly unexplored as regards the zooplankton of the inland waters, and consequently their calanoid fauna is still unknown. The Tavoliere plateau (in northern Apulia, south-west of the Gargano promontory) is the larger among these subareas, nevertheless it is considered as one of the cold-spots of biodiversity for Italian fauna (Stoch 2006b). For this reason, we hypothesize that the contribution of the Tavoliere plateau to the Apulian Calanoid fauna should be very small.

\subsection{Species distribution}

The nMDS plot of temporary waters highlights the differences between the subareas, mainly for the stronger grouping of Mixodiaptomus lilljeborgi (present only in the Gargano subarea) and M. kupelwieseri (present only in the Salento subarea). Eudiaptomus vulgaris, the only species present both in temporary and permanent waters, is the second species (in terms of number of sites in which it is present) peculiar to the Gargano subarea. Conversely a larger number of species characterize 
the temporary ponds of Salento, they are Diaptomus cyaneus, Hemidiaptomus ingens and Mixodiaptomus incrassatus.

Arctodiaptomus salinus, detected only in a single permanent coastal salt lake, has to be added to the list of species that differentiate the calanoid fauna of Salento. At present the site in Salento hosting A. salinus represents the only site showing this species in all the Italian mainland. The presence of this species in Apulia is an element in common with two other Italian faunal provinces, Sardinia and Sicily.

The chorotype analysis revealed that the chorotypes represented by Apulian Calanoida are mainly Mediterranean and then Palearctic. A slightly different result was found in a recent study (Marrone et al. 2007) on 17 anomopod taxa of 18 Apulian inland waters, where the Palearctic species seem to characterize the region more than the Mediterranean ones. The different results could be influenced by the different number of sampled sites in the two studies. On the other hand there is an element in common between the study of Marrone et al. (2007) and the present research: the lack of typical and strictly eastern taxa among the species detected, in spite of the Aegeid paleogeographic history of Apulia. Nevertheless considering the distribution of Diaptomus serbicus and Hemidiaptomus gurney in the European-Mediterranean area (Dussart \& Defaye 2002), these two species could be considered the only two Apulian Calanoida with a slight eastern gravitation. Moreover the Gargano subarea shares with the Apennine province the presence of the Asiatic-European species Eudiaptomus vulgaris. The central Apulian subarea, in spite of the low number of species, displays a similarity with the Apennines as well, due to the presence of Copidodiaptomus steueri.

Conversely, Hemidiaptomus ingens and Diaptomus cyaneus, species with a western gravitation and present also in North Africa (Dussart \& Defaye 2002), occur only in the Salento subarea, that is the Apulian subarea with a more pronounced Mediterranean climate (Macchia et al. 2000).

The cluster analysis, based on Calanoida of the Apulian subareas and those of the geographically close areas, reveals the presence of 'two different Apulias' (Gargano and Salento). This result is in accordance with what was found by Stoch (2006b) who proposed two different sectors for the Apulian faunal province, mainly based on herpetofauna and terrestrial and inland water invertebrates. At the same time, the cluster analysis suggests that Calanoida is not a suitable taxa to define the Apulian faunal province. The scenario described by the inland water Calanoida suggests that even if Apulia has a predominantly Mediterranean assessment on the whole, Gargano is more similar to the Apennine province, while Salento is more similar to the Sicilian province. The reason for these similarities might be explained by climatic causes and environmental reasons. Gargano is the Apulian subarea with the colder microclimate and it is geographically very close to the Apennines; conversely Salento is warmer, like Sicily, with steno-Mediterranean characteristics. This set of elements, together with the lack of endemic species, suggests that the current Calanoida assessment in Apulia appears to be rather 'young' and could derive from a recent colonization, which very likely started only in the post-glacial period. In addition, climate and environmental conditions could have also favoured a calanoid fauna characterised by species able to produce resting eggs (see Gauthier 1928 and Kiefer 1978), and thus adapted to surviving in the temporary waters, the most common typology of surface inland water in Apulia.

Considering that Apulia covers a surface of less than $20,000 \mathrm{~km}^{2}$, the number of Calanoida detected appears high. Such a diversity likely reflects an environmental context (mainly determined by climatic conditions and the geographic location) that confers on this area a role of transitional territory where Mediterranean, European and Palearctic species co-occur.

\section{ACKNOWLEDGEMENTS}

We wish to thank all the people who allow us to realize this research: Francesca Adorni, owner of Bosco Lucci estate, Giuseppe Monte (L.I.P.U. - Brindisi), Cosimo Bonomo (Faunal - Environmental Police - district of Brindisi). A special thanks to Dr. Tommaso Scirocco for his precious help in the sampling of the cutini in the Gargano area. We are in particular grateful to Dr. Fabio Stoch and Dr. Federico Marrone for precious exchanges of information which encouraged the writing of this paper and their critical suggestions on the first draft of the manuscript. This research was in part supported by the banking foundation "Fondazione Cassa di Risparmio di Puglia".

\section{REFERENCES}

Alfonso, G. \& G. Belmonte. 2008. Expanding distribution of Boeckella triarticulata (Thomson 1883) (Copepoda: Calanoida) in Southern Italy. Aquatic Invasions, 3(2): 247-251.

Alfonso, G., G. Belmonte, F. Marrone \& L. Naselli-Flores. 2010. Does lake age affect zooplankton diversity in Mediterranean lakes and reservoirs? A case study from southern Italy. Hydrobiologia, 653: 149-164.

Alonso, M. 1998. Las lagunas de la Espanã peninsular. Limnetica, 15: $1-176$.

Bayly, I.A.E. 1992. The non-marine Centropagidae (Copepoda: Calanoida) of the world. SPB Academic Publishers, The Hague: $30 \mathrm{pp}$.

Belmonte, G., G. Alfonso \& S. Moscatello. 2006. Copepod fauna in small ponds of the Pollino National Park (South Italy), with notes on seasonality and biometry of species. J. Limnol., 65(2): 107-113.

Boxshall, G.A. \& S.H. Halsey. 2004. An introduction to copepod diversity. London: The Ray Society Series, 166: 966 pp.

Brancelj, A. 1996. Favna rakov ceponozcev (Crustacea: Copepoda) v celinskih vodah. The fauna of copepods (Crustacea: Copepoda) in inland waters. In: Narava Slovenije, stanje in perspektive. Drustvo Ekologov Slovenije; Ljubljana. Nature of Slovenia, present status and future. Ecological Society of Slovenia, Ljubljana: 242-246. 
Cannicci, G. 1939. Sulla distribuzione della Poppella guerney Richard (Calanipeda aquaedulcis Kritsch.) negli stagni salmastri. Int. Revue ges. Hydrobiol., 38: 489-503.

Cavallo, A. \& G. Belmonte. 1995. Lo zooplancton dello stagno costiero Le Cesine (LE) (Maggio 1993-Agosto 1994). Thalassia Salentina, 21: 51-60.

Clarke, K.R. \& R.N. Gorley. 2006. PRIMER v6: User Manual/ Tutorial. PRIMER-E, Plymouth.

Colwell, R.K. 2009. EstimateS: Statistical estimation of species richness and shared species from samples. Version 8.2. User's Guide and application published at: http://purl. oclc.org/estimates.

Doglioni, C., M. Tropeano, F. Mongelli \& P. Pieri. 1996. Middle-late Pleistocene uplift of Puglia: an "anomaly" in the Apennine foreland. Mem. Soc. Geol. It., 51: 101-117.

Dussart, B. 1967. Les copépodes des eaux continentales d'Europe Occidentale. Tome I: Calanoïdes et Harpacticoïdes. Edition N. Boubee \& Cie, Paris: 500 pp.

Dussart, B. 1989. Crustacés Copépodes Calanoïdes des eaux interieures africanes. Crustaceana, Suppl. 15: 205 pp.

Dussart, B. H. \& D. Defaye. 2001. Introduction to the Copepoda. $\left(2^{\text {nd }}\right.$ ed.). Guides to the Identification of the Microinvertebrates of the Continental Waters of the World, 16. SPB Academic Publishing: 344 pp.

Dussart, B. \& D. Defaye. 2002. World Directory of Calanoida Copepoda of Inland Waters. I. Calaniformes. Backhuys Publishers, Leiden: 276 pp.

Einsle, U. 1993. Crustacea Copepoda Calanoida und Cyclopoida. Süßwasserfauna von Mitteleuropa 8/4. Gustav Fischer Verlag, Stuttgart: 208 pp.

Gauthier, H. 1928. Recherches sur la faune des eaux continentales de l'Algérie et de la Tunisie. Imprimerie Minerva, Alger: 419 pp.

Güher, H. \& T. Kirgiz. 2004. The Copepoda (Crustacea) Freshwater Fauna of Turkish Thrace Region (Edirne, Kirklareli, Tekirda.). Pak. J. Biol. Sci., 7(5): 834-837.

ISTAT. 2004. Annali di Statistica - Regione Puglia: territorio. Istituto Nazionale di Statistica, Rome.

Jaume, D. 1989-1990. Calanoides (Crustacea: Copepoda) de les aigues continentals Baleariques. Boll. Soc. Hist. Nat. Balears, 33: 207-219.

Kiefer, F. 1978. Das Zooplankton der Binnengewässer. Freilebende Copepoda. Die Binnengewässer. Band 26 Teil 2. E. Schweizerbart'sche Verlagbuchhandlung, Stuttgart: 343 pp.

Macchia, F., V. Cavallaro, L. Forte \& M. Terzi. 2000. Vegetazione e clima della Puglia. In: S. Marchiori, F. De Castro \& A. Myrta (Eds), La cooperazione italo-albanese per la valorizzazione della biodiversità. CIHEAM, Bari : 33-49.

Marrone, F. 2006. The microcrustacean fauna of Sicily and the central Mediterranean Sea area - Current knowledge and gaps to be filled. Pol. J. Ecol., 54(4): 681-685.

Marrone, F. \& L. Naselli-Flores. 2004. First record and morphological features of Hemidiaptomus (Occidodiaptomus) ingens (Gurney 1909) (Copepoda Calanoida) in Italy. J. Limnol., 63(2): 250-255.

Marrone, F., G. Alfonso \& L. Naselli-Flores. 2007. On Daphnia (Ctenodaphnia) similis Claus, 1877 and other interesting anomopods (Crustacea, Branchiopoda) from Apulia. Thalassia Salentina, 30: 45-55.

Marrone, F., S. Lo Brutto \& M. Arculeo. 2010. Molecular evidence for the presence of cryptic evolutionary lineages in the freshwater copepod genus Hemidiaptomus G.O. Sars 1903 (Calanoida, Diaptomidae). Hydrobiologia, 644: 115-125.

Mattei, M., C. Kissel, L. Sagnotti, R. Funiciello \& C. Faccenna. 1996. Lack of late Miocene to present rotation in the northern Tyrrhenian margin (Italy); a constraint on geodynamic evolution. In: Morris, A. \& D.H. Tarling (Eds), Palaeomagnetism and tectonics of the Mediterranean region. Geological Society Special Publications, 105: 141-146.

Meulenkamp, J.E. \& W. Sissingh. 2003. Tertiary palaeogeography and tectonostratigraphic evolution of the Northern and Southern Peri-Tethys platforms and the intermediate domains of the African-Eurasian convergent plate boundary zone. Palaeogeogr. Palaeoclimatol. Palaeoecol., 196: 209-228

Minelli, A., S. Ruffo \& A. Vigna Taglianti. 2006. The Italian faunal provinces. In: S. Ruffo \& F. Stoch (Eds), Checklist and distribution of the Italian fauna. Memorie del Museo Civico di Storia Naturale di Verona - 2. serie - Sezione Scienze della Vita, 17: 37-39.

Petkovski, T.K. 1983. Calanoides - Calanoida (Crustacea Copepoda). Faune de Macedonie, V. Musée Histoire Naturelle de Macedonie, Skopje: $182 \mathrm{pp}$.

Ranga Reddy, Y. 1994. Copepoda: Calanoida: Diaptomidae (Key to the genera Heliodiaptomus, Neodiaptomus, Phyllodiaptomus, Eodiaptomus, Arctodiaptomus and Sinodiaptomus). Guides to the Identification of the Microinvertebrates of the Continental Waters of the World. v. 5. SPB Academic Publishing, Amsterdam: $221 \mathrm{pp}$.

Ricchetti, G., N. Ciaranfi, E. Luperto Sinni, F. Monelli \& P. Pieri. 1988. Geodinamica ed evoluzione sedimentaria e tettonica dell'Avampaese Apulo. Mem. Soc. Geol. It., 41: $57-82$.

Ruffo S. \& F. Stoch (Eds). 2006. Checklist and distribution of the Italian fauna. Memorie del Museo Civico di Storia Naturale di Verona - 2. serie - Sezione Scienze della Vita, 17: $303 \mathrm{pp}$.

Scirocco, T., P. Ventrella, L. Cilenti, A. Specchiulli, M. Florio \& P. Breber. 2008. Contributo alla conoscenza dell'idrofauna invertebrata e degli anfibi delle acque temporanee del Parco Nazionale del Gargano. Atti Soc. it. Sci. nat. Museo civ. Stor. nat. Milano, 149(1): 17-23.

Shehu, M., F. Serravalle, G. Alfonso, S. Moscatello \& G. Belmonte. 2010. The alpine Lake Gistova (Mount Gramos, Albania-Greece border) biodiversity of an isolated microcosm. Thalassia Salentina, 32: 51-60.

Stella, E. 1984. Copepoda: Calanoida. XXI Fauna d'Italia. Calderini, Bologna: $101 \mathrm{pp}$.

Stoch, F. 2006a. Crustacea Copepoda Calanoida. In: Ruffo S., Stoch F. (Eds), Checklist and distribution of the Italian fauna. Memorie del Museo Civico di Storia Naturale di Verona - 2. Serie - Sezione Scienze della Vita, 17: 91-92.

Stoch, F. 2006b. L'assetto zoogeografico dell'Appennino centro-settentrionale. Biogeographia, 27: 129-150.

Ternjej, I. \& I. Stanković. 2007. Checklist of fresh and brackish water free-living copepods (Crustacea: Calanoida and Cyclopoida) from Croatia. Zootaxa, 1585: 45-57.

Vigna Taglianti, A., P.A. Audisio, C. Belfiore, M. Biondi, M.A. Bologna, G.M. Carpaneto, A. De Biase, S. De Felici, E. Piattella, T. Racheli, M. Zapparoli \& S. Zoia. 1992. Riflessioni di gruppo sui corotipi fondamentali della fauna W-Paleartica ed in particolare italiana. Biogeographia, 16: 159-179.

Zito, G., L. Ruggiero \& F. Zuanni. 1991. Aspetti meteorologici e climatici della Puglia. Progetto Strategico C.N.R. Clima Ambiente e Territorio nel Mezzogiorno. $1^{\circ}$ Workshop. Taormina 11 Dicembre 1989, Atti: 43-73. 


\section{A P P EN DIX}

List of the sampling sites. Each site is described by: a code; the name of the locality with the administrative province in brackets; the hydroperiod ( $\mathrm{T}=$ temporary, $\mathrm{P}=$ permanent); latitude North and longitude East referred to WGS84 datum. Codes of the sites hosting Calanoida are in italic. $\mathrm{S}=$ Salento; $\mathrm{C}=$ Central Apulia; $\mathrm{G}=$ Gargano.

\begin{tabular}{|c|c|c|c|c|c|c|}
\hline Code & Name & Hydroperiod & Latitude N & Longitude E & Altitude (m a.s.l.) & Subarea \\
\hline PU001 & Sandonaci 1 (BR) & $\mathrm{T}$ & $40^{\circ} 26^{\prime} 10^{\prime \prime}$ & $17^{\circ} 55^{\prime} 07^{\prime \prime}$ & 38 & $\mathrm{~S}$ \\
\hline PU002 & Sandonaci 2 (BR) & $\mathrm{T}$ & $40^{\circ} 26^{\prime} 09^{\prime \prime}$ & $17^{\circ} 55^{\prime} 10^{\prime \prime}$ & 39 & $\mathrm{~S}$ \\
\hline PU003 & Sandonaci 3 (BR) & $\mathrm{T}$ & $40^{\circ} 26^{\prime} 13^{\prime \prime}$ & $17^{\circ} 55^{\prime} 12^{\prime \prime}$ & 39 & $\mathrm{~S}$ \\
\hline PU004 & Sandonaci 4 (BR) & $\mathrm{T}$ & $40^{\circ} 26^{\prime} 24^{\prime \prime}$ & $17^{\circ} 55^{\prime} 05^{\prime \prime}$ & 37 & S \\
\hline PU005 & Francavilla F. 1 (BR) & $\mathrm{T}$ & $40^{\circ} 32^{\prime} 11^{\prime \prime}$ & $17^{\circ} 32^{\prime} 55^{\prime \prime}$ & 140 & S \\
\hline PU006 & Francavilla F. 2 (BR) & $\mathrm{P}$ & $40^{\circ} 32^{\prime} 11^{\prime \prime}$ & $17^{\circ} 32^{\prime} 55^{\prime \prime}$ & 140 & $\mathrm{~S}$ \\
\hline PU007 & Francavilla F. 3 (BR) & $\mathrm{T}$ & $40^{\circ} 31^{\prime} 48^{\prime \prime}$ & $17^{\circ} 33^{\prime} 29^{\prime \prime}$ & 139 & $\mathrm{~S}$ \\
\hline PU008 & Francavilla F. 4 (BR) & $\mathrm{P}$ & $40^{\circ} 32^{\prime} 42^{\prime \prime}$ & $17^{\circ} 30^{\prime} 45^{\prime \prime}$ & 156 & $\mathrm{~S}$ \\
\hline PU009 & Specchia (LE) & $\mathrm{T}$ & $39^{\circ} 56^{\prime} 56^{\prime \prime}$ & $18^{\circ} 17^{\prime} 56^{\prime \prime}$ & 108 & S \\
\hline PU010 & San Pancrazio (BR) & $\mathrm{T}$ & $40^{\circ} 24^{\prime} 27^{\prime \prime}$ & $17^{\circ} 50^{\prime} 31^{\prime \prime}$ & 61 & S \\
\hline PU011 & Bosco Lucci (BR) & $\mathrm{T}$ & $40^{\circ} 34^{\prime} 25^{\prime \prime}$ & $17^{\circ} 51^{\prime} 42^{\prime \prime}$ & 51 & $\mathrm{~S}$ \\
\hline PU012 & Miggiano (LE) & $\mathrm{T}$ & $39^{\circ} 58^{\prime} 07^{\prime \prime}$ & $18^{\circ} 18^{\prime} 20^{\prime \prime}$ & 104 & S \\
\hline PU013 & Veglie 1 (LE) & $\mathrm{T}$ & $40^{\circ} 20^{\prime} 19^{\prime \prime}$ & $17^{\circ} 59^{\prime} 52^{\prime \prime}$ & 43 & S \\
\hline PU014 & Veglie 2 (LE) & $\mathrm{T}$ & $40^{\circ} 20^{\prime} 16^{\prime \prime}$ & $17^{\circ} 59^{\prime} 47^{\prime \prime}$ & 44 & $\mathrm{~S}$ \\
\hline PU015 & Bosco Cerano (BR) & $\mathrm{T}$ & $40^{\circ} 32^{\prime} 42^{\prime \prime}$ & $18^{\circ} 00^{\prime} 47^{\prime \prime}$ & 12 & S \\
\hline PU016 & Bosco Rauccio 1 (LE) & $\mathrm{P}$ & $40^{\circ} 27^{\prime} 49^{\prime \prime}$ & $18^{\circ} 09^{\prime} 41^{\prime \prime}$ & 3 & $\mathrm{~S}$ \\
\hline PU017 & Otranto (LE) & $\mathrm{P}$ & $40^{\circ} 07^{\prime} 55^{\prime \prime}$ & $18^{\circ} 30^{\prime} 09^{\prime \prime}$ & 40 & $\mathrm{~S}$ \\
\hline PU018 & Veglie 3 (LE) & $\mathrm{T}$ & $40^{\circ} 20^{\prime} 23^{\prime \prime}$ & $17^{\circ} 58^{\prime} 48^{\prime \prime}$ & 46 & S \\
\hline PU019 & Alimini P (LE) & $\mathrm{P}$ & $40^{\circ} 10^{\prime} 50^{\prime \prime}$ & $18^{\circ} 26^{\prime} 45^{\prime \prime}$ & 0 & $\mathrm{~S}$ \\
\hline PU020 & Patula Mancina (LE) & $\mathrm{T}$ & $39^{\circ} 59^{\prime} 10^{\prime \prime}$ & $18^{\circ} 18^{\prime} 35^{\prime \prime}$ & 1 & $\mathrm{~S}$ \\
\hline PU021 & P.ta Contessa (BR) & $\mathrm{P}$ & $40^{\circ} 36^{\prime} 58^{\prime \prime}$ & $18^{\circ} 01^{\prime} 14^{\prime \prime}$ & 0 & $\mathrm{~S}$ \\
\hline PU022 & P.ta Grossa (LE) & $\mathrm{T}$ & $40^{\circ} 17^{\prime} 28^{\prime \prime}$ & $17^{\circ} 47^{\prime} 43^{\prime \prime}$ & 1 & $\mathrm{~S}$ \\
\hline PU023 & Le Cesine (LE) & $\mathrm{P}$ & $40^{\circ} 21^{\prime} 37^{\prime \prime}$ & $18^{\circ} 19^{\prime} 56^{\prime \prime}$ & 0 & $\mathrm{~S}$ \\
\hline PU024 & Manduria 1 (TA) & $\mathrm{T}$ & $40^{\circ} 22^{\prime} 58^{\prime \prime}$ & $17^{\circ} 38^{\prime} 24^{\prime \prime}$ & 81 & $\mathrm{~S}$ \\
\hline PU025 & Manduria 2 (TA) & $\mathrm{T}$ & $40^{\circ} 19^{\prime} 53^{\prime \prime}$ & 17³9'13" & 83 & $\mathrm{~S}$ \\
\hline PU026 & Cutino d'Otri (FG) & $\mathrm{T}$ & $41^{\circ} 47^{\prime} 46^{\prime \prime}$ & $16^{\circ} 01^{\prime} 43^{\prime \prime}$ & 785 & $\mathrm{G}$ \\
\hline PU027 & Cutino d'Umbra (FG) & $\mathrm{P}$ & $41^{\circ} 49^{\prime} 01^{\prime \prime}$ & $15^{\circ} 59^{\prime} 45^{\prime \prime}$ & 804 & G \\
\hline PU028 & Cutino Revitali (FG) & $\mathrm{T}$ & $41^{\circ} 51^{\prime} 51^{\prime \prime}$ & $16^{\circ} 03^{\prime} 42^{\prime \prime}$ & 270 & G \\
\hline PU029 & Cutino Sciurello (FG) & $\mathrm{T}$ & $41^{\circ} 52^{\prime} 04^{\prime \prime}$ & $16^{\circ} 02^{\prime} 31^{\prime \prime}$ & 360 & G \\
\hline PU030 & Valle Tagliata 1 (FG) & $\mathrm{T}$ & $41^{\circ} 45^{\prime} 45^{\prime \prime}$ & $16^{\circ} 03^{\prime} 48^{\prime \prime}$ & 640 & G \\
\hline PU031 & Valle Tagliata 2 (FG) & $\mathrm{T}$ & $41^{\circ} 46^{\prime} 29^{\prime \prime}$ & $16^{\circ} 02^{\prime} 11^{\prime \prime}$ & 670 & G \\
\hline PU032 & Valle Tagliata 3 (FG) & $\mathrm{T}$ & $41^{\circ} 45^{\prime} 32^{\prime \prime}$ & $16^{\circ} 03^{\prime} 34^{\prime \prime}$ & 640 & $\mathrm{G}$ \\
\hline PU033 & Cutino Scaranappe (FG) & $\mathrm{T}$ & $41^{\circ} 48^{\prime} 30^{\prime \prime}$ & $15^{\circ} 58^{\prime} 25^{\prime \prime}$ & 733 & G \\
\hline PU034 & Cutino del Lupo (FG) & $\mathrm{T}$ & $41^{\circ} 48^{\prime} 09^{\prime \prime}$ & $15^{\circ} 58^{\prime} 50^{\prime \prime}$ & 740 & G \\
\hline PU035 & Lago S. Egidio (FG) & $\mathrm{T}$ & $41^{\circ} 42^{\prime} 36^{\prime \prime}$ & $15^{\circ} 47^{\prime} 54^{\prime \prime}$ & 473 & G \\
\hline PU036 & S.S. $272(\mathrm{FG})$ & $\mathrm{T}$ & $41^{\circ} 43^{\prime} 16^{\prime \prime}$ & $15^{\circ} 53^{\prime} 10^{\prime \prime}$ & 605 & G \\
\hline PU037 & Cutino Pandolfi (FG) & $\mathrm{T}$ & $41^{\circ} 44^{\prime} 35^{\prime \prime}$ & $15^{\circ} 54^{\prime} 55^{\prime \prime}$ & 664 & G \\
\hline PU038 & Rignano 1 (FG) & $\mathrm{P}$ & $41^{\circ} 42^{\prime} 01^{\prime \prime}$ & $15^{\circ} 35^{\prime} 48^{\prime \prime}$ & 663 & G \\
\hline PU039 & Rignano 2 (FG) & $\mathrm{P}$ & $41^{\circ} 42^{\prime} 00^{\prime \prime}$ & $15^{\circ} 35^{\prime} 51^{\prime \prime}$ & 663 & G \\
\hline PU040 & Fantina Lesina (FG) & $\mathrm{P}$ & $41^{\circ} 53^{\prime} 28^{\prime \prime}$ & $15^{\circ} 23^{\prime} 46^{\prime \prime}$ & 2 & G \\
\hline PU041 & Casarano (LE) & $\mathrm{P}$ & $40^{\circ} 00^{\prime} 13^{\prime \prime}$ & $18^{\circ} 08^{\prime} 34^{\prime \prime}$ & 68 & $\mathrm{~S}$ \\
\hline PU042 & Bosco Mangiato (TA) & $\mathrm{P}$ & $40^{\circ} 44^{\prime} 27^{\prime \prime}$ & $17^{\circ} 14^{\prime} 42^{\prime \prime}$ & 432 & $\mathrm{C}$ \\
\hline PU043 & S.P. 239 (BA) & $\mathrm{T}$ & $40^{\circ} 47^{\prime} 02^{\prime \prime}$ & $17^{\circ} 11^{\prime} 42^{\prime \prime}$ & 443 & $\mathrm{C}$ \\
\hline PU044 & Cellaforza 3 (BA) & $\mathrm{T}$ & $40^{\circ} 53^{\prime} 55^{\prime \prime}$ & $16^{\circ} 29^{\prime} 48^{\prime \prime}$ & 484 & $\mathrm{C}$ \\
\hline PU045 & Gurlamanna (BA) & $\mathrm{P}$ & $40^{\circ} 54^{\prime} 32^{\prime \prime}$ & $16^{\circ} 25^{\prime} 32^{\prime \prime}$ & 531 & $\mathrm{C}$ \\
\hline PU046 & S. Magno (BA) & $\mathrm{P}$ & $41^{\circ} 02^{\prime} 20^{\prime \prime}$ & $16^{\circ} 20^{\prime} 40^{\prime \prime}$ & 485 & $\mathrm{C}$ \\
\hline PU047 & Taverna Nuova 1 (BA) & $\mathrm{T}$ & $40^{\circ} 59^{\prime} 42^{\prime \prime}$ & $16^{\circ} 18^{\prime} 12^{\prime \prime}$ & 608 & $\mathrm{C}$ \\
\hline PU048 & Taverna Nuova 2 (BA) & $\mathrm{T}$ & $40^{\circ} 59^{\prime} 39^{\prime \prime}$ & $16^{\circ} 17^{\prime} 56^{\prime \prime}$ & 600 & $\mathrm{C}$ \\
\hline PU049 & Valesio (BR) & $\mathrm{T}$ & $40^{\circ} 30^{\prime} 35^{\prime \prime}$ & $18^{\circ} 01^{\prime} 53^{\prime \prime}$ & 33 & $\mathrm{~S}$ \\
\hline PU050 & T.rre S. Gennaro (BR) & $\mathrm{P}$ & $40^{\circ} 32^{\prime} 01^{\prime \prime}$ & $18^{\circ} 04^{\prime} 28^{\prime \prime}$ & 7 & $\mathrm{~S}$ \\
\hline PU051 & S. Cataldo (BA) & $\mathrm{P}$ & $40^{\circ} 54^{\prime} 59^{\prime \prime}$ & $16^{\circ} 17^{\prime} 18^{\prime \prime}$ & 428 & $\mathrm{C}$ \\
\hline PU052 & Masseria Cristo (BA) & $\mathrm{P}$ & $40^{\circ} 55^{\prime} 36^{\prime \prime}$ & $16^{\circ} 16^{\prime} 42^{\prime \prime}$ & 441 & $\mathrm{C}$ \\
\hline PU053 & Pilone (BA) & $\mathrm{T}$ & $40^{\circ} 55^{\prime} 14^{\prime \prime}$ & $16^{\circ} 14^{\prime} 47^{\prime \prime}$ & 450 & $\mathrm{C}$ \\
\hline PU054 & Fornasiello (BA) & $\mathrm{T}$ & $40^{\circ} 55^{\prime} 36^{\prime \prime}$ & $16^{\circ} 17^{\prime} 02^{\prime \prime}$ & 435 & $\mathrm{C}$ \\
\hline PU055 & Cardinale (BA) & $\mathrm{P}$ & $40^{\circ} 53^{\prime} 49^{\prime \prime}$ & $16^{\circ} 13^{\prime} 28^{\prime \prime}$ & 297 & $\mathrm{C}$ \\
\hline PU056 & Adogna (BA) & $\mathrm{T}$ & $40^{\circ} 55^{\prime} 42^{\prime \prime}$ & $16^{\circ} 14^{\prime} 47^{\prime \prime}$ & 451 & $\mathrm{C}$ \\
\hline PU057 & Strappete (BA) & $\mathrm{T}$ & $41^{\circ} 03^{\prime} 08^{\prime \prime}$ & $16^{\circ} 26^{\prime} 30^{\prime \prime}$ & 331 & $\mathrm{C}$ \\
\hline PU058 & Bellimento (LE) & $\mathrm{T}$ & $40^{\circ} 11^{\prime} 47^{\prime \prime}$ & $17^{\circ} 55^{\prime} 22^{\prime \prime}$ & 4 & $\mathrm{~S}$ \\
\hline PU059 & Laccu Feretru (LE) & $\mathrm{T}$ & $40^{\circ} 13^{\prime} 00^{\prime \prime}$ & $18^{\circ} 11^{\prime} 07^{\prime \prime}$ & 69 & $\mathrm{~S}$ \\
\hline PU060 & Li Puzzi (LE) & $\mathrm{P}$ & $40^{\circ} 11^{\prime} 45^{\prime \prime}$ & $18^{\circ} 13^{\prime} 46^{\prime \prime}$ & 83 & $\mathrm{~S}$ \\
\hline PU061 & Carmiano (LE) & $\mathrm{T}$ & $40^{\circ} 20^{\prime} 53^{\prime \prime}$ & $18^{\circ} 03^{\prime} 07^{\prime \prime}$ & 27 & $\mathrm{~S}$ \\
\hline
\end{tabular}

(continued) 
Appendix. Continuation.

\begin{tabular}{|c|c|c|c|c|c|c|}
\hline Code & Name & Hydroperiod & Latitude N & Longitude $\mathrm{E}$ & Altitude (m a.s.1.) & SubArea \\
\hline PU062 & Padula (BA) & $\mathrm{T}$ & $40^{\circ} 59^{\prime} 32^{\prime \prime}$ & $17^{\circ} 07^{\prime} 51^{\prime \prime}$ & 152 & $\mathrm{C}$ \\
\hline PU063 & Chienna (BA) & $\mathrm{T}$ & $40^{\circ} 58^{\prime} 09^{\prime \prime}$ & $17^{\circ} 04^{\prime} 23^{\prime \prime}$ & 176 & $\mathrm{C}$ \\
\hline PU064 & Sassano (BA) & $\mathrm{T}$ & $40^{\circ} 58^{\prime} 06^{\prime \prime}$ & $17^{\circ} 05^{\prime} 51^{\prime \prime}$ & 182 & $\mathrm{C}$ \\
\hline PU065 & S. Vito (BA) & $\mathrm{T}$ & $40^{\circ} 58^{\prime} 46^{\prime \prime}$ & $17^{\circ} 07^{\prime} 59^{\prime \prime}$ & 171 & $\mathrm{C}$ \\
\hline PU066 & Castiglione (BA) & $\mathrm{T}$ & $40^{\circ} 55^{\prime} 36^{\prime \prime}$ & $17^{\circ} 07^{\prime} 42^{\prime \prime}$ & 214 & $\mathrm{C}$ \\
\hline PU067 & Cutino T.rre Palermo (FG) & $\mathrm{T}$ & $41^{\circ} 47 ' 36^{\prime \prime}$ & $16^{\circ} 02^{\prime} 35^{\prime \prime}$ & 797 & G \\
\hline PU068 & S.S. $528(\mathrm{FG})$ & $\mathrm{T}$ & $41^{\circ} 46^{\prime} 07^{\prime \prime}$ & $15^{\circ} 59^{\prime} 01^{\prime \prime}$ & 610 & G \\
\hline PU069 & Cutino Pandolfi (FG) & $\mathrm{T}$ & $41^{\circ} 45^{\prime} 49^{\prime \prime}$ & $15^{\circ} 53^{\prime} 04^{\prime \prime}$ & 591 & G \\
\hline PU070 & Valle Tagliata 4 (FG) & $\mathrm{T}$ & $41^{\circ} 45^{\prime} 31^{\prime \prime}$ & $16^{\circ} 03^{\prime} 35^{\prime \prime}$ & 640 & G \\
\hline PU071 & Valle Tagliata 5 (FG & $\mathrm{T}$ & $41^{\circ} 46^{\prime} 24^{\prime \prime}$ & $16^{\circ} 02^{\prime} 48^{\prime \prime}$ & 675 & G \\
\hline PU072 & Valle Tagliata 6 (FG) & $\mathrm{T}$ & $41^{\circ} 46^{\prime} 36^{\prime \prime}$ & $16^{\circ} 02^{\prime} 32^{\prime \prime}$ & 684 & $\mathrm{G}$ \\
\hline PU073 & Margherita di Savoia (FG) & $\mathrm{P}$ & $41^{\circ} 24^{\prime} 23^{\prime \prime}$ & $16^{\circ} 00^{\prime} 54^{\prime \prime}$ & 1 & $\mathrm{G}$ \\
\hline PU074 & Basentello (BA) & $\mathrm{P}$ & $40^{\circ} 51^{\prime} 09^{\prime \prime}$ & $16^{\circ} 14^{\prime} 13^{\prime \prime}$ & 275 & $\mathrm{C}$ \\
\hline PU075 & Le Cesine 1 (LE) & $\mathrm{T}$ & $40^{\circ} 21^{\prime} 08^{\prime \prime}$ & $18^{\circ} 20^{\prime} 02^{\prime \prime}$ & 2 & $\mathrm{~S}$ \\
\hline PU076 & Le Cesine 2 (LE) & $\mathrm{T}$ & $40^{\circ} 21^{\prime} 05^{\prime \prime}$ & $18^{\circ} 20^{\prime} 05^{\prime \prime}$ & 2 & $\mathrm{~S}$ \\
\hline PU077 & Le Cesine 3 (LE) & $\mathrm{T}$ & $40^{\circ} 21^{\prime} 11^{\prime \prime}$ & $18^{\circ} 19^{\prime} 46^{\prime \prime}$ & 5 & $\mathrm{~S}$ \\
\hline PU078 & Toritto (BA) & $\mathrm{T}$ & $40^{\circ} 50^{\prime} 12^{\prime \prime}$ & $16^{\circ} 33^{\prime} 20^{\prime \prime}$ & 200 & $\mathrm{C}$ \\
\hline PU079 & Lamie di Olimpia (BA) & $\mathrm{T}$ & $40^{\circ} 47^{\prime} 24^{\prime \prime}$ & $17^{\circ} 21^{\prime} 27^{\prime \prime}$ & 349 & $\mathrm{C}$ \\
\hline PU080 & S. Giuseppe (BA) & $\mathrm{T}$ & $40^{\circ} 55^{\prime} 33^{\prime \prime}$ & $16^{\circ} 26^{\prime} 27^{\prime \prime}$ & 515 & $\mathrm{C}$ \\
\hline PU081 & Tombolo Lesina 1 (FG) & $\mathrm{T}$ & $41^{\circ} 54^{\prime} 20^{\prime \prime}$ & $15^{\circ} 20^{\prime} 50^{\prime \prime}$ & 15 & G \\
\hline PU082 & Tombolo Lesina 2 (FG) & $\mathrm{T}$ & $41^{\circ} 53^{\prime} 51^{\prime \prime}$ & $15^{\circ} 21^{\prime} 05^{\prime \prime}$ & 6 & G \\
\hline PU083 & Irchio $(\mathrm{FG})$ & $\mathrm{T}$ & $41^{\circ} 52^{\prime} 27^{\prime \prime}$ & $15^{\circ} 48^{\prime} 45^{\prime \prime}$ & 61 & G \\
\hline PU084 & T.rre Mileto (FG) & $\mathrm{T}$ & $41^{\circ} 54^{\prime} 48^{\prime \prime}$ & $15^{\circ} 35^{\prime} 37^{\prime \prime}$ & 14 & $\mathrm{G}$ \\
\hline PU085 & Zappino (FG) & $\mathrm{T}$ & $41^{\circ} 533^{\prime} 31^{\prime \prime}$ & $15^{\circ} 24^{\prime} 07^{\prime \prime}$ & 9 & G \\
\hline PU086 & Oasi LIPU Lesina 1 (FG) & $\mathrm{T}$ & $41^{\circ} 53^{\prime} 42^{\prime \prime}$ & $15^{\circ} 21^{\prime} 10^{\prime \prime}$ & 8 & $\mathrm{G}$ \\
\hline PU087 & Oasi LIPU Lesina 2 (FG) & $\mathrm{T}$ & $41^{\circ} 53^{\prime} 45^{\prime \prime}$ & $15^{\circ} 21^{\prime} 17^{\prime \prime}$ & 12 & $\mathrm{G}$ \\
\hline PU088 & Tombolo Varano 1 (FG) & $\mathrm{T}$ & $41^{\circ} 55^{\prime} 04^{\prime \prime}$ & $15^{\circ} 47^{\prime} 36^{\prime \prime}$ & 7 & $\mathrm{G}$ \\
\hline PU089 & Tombolo Varano 2 (FG) & $\mathrm{T}$ & $41^{\circ} 54^{\prime} 48^{\prime \prime}$ & $15^{\circ} 35^{\prime} 37^{\prime \prime}$ & 7 & G \\
\hline PU090 & S. Nazario 1 (FG) & $\mathrm{T}$ & $41^{\circ} 51^{\prime} 10^{\prime \prime}$ & $15^{\circ} 27^{\prime} 04^{\prime \prime}$ & 16 & G \\
\hline PU091 & S. Nazario 2 (FG) & $\mathrm{T}$ & $41^{\circ} 51^{\prime} 10^{\prime \prime}$ & $15^{\circ} 27^{\prime} 04^{\prime \prime}$ & 16 & G \\
\hline PU092 & irrigation pond $1(\mathrm{FG})$ & $\mathrm{P}$ & $41^{\circ} 53^{\prime} 52^{\prime \prime}$ & $15^{\circ} 19^{\prime} 34^{\prime \prime}$ & 11 & G \\
\hline PU093 & irrigation pond $2(\mathrm{FG})$ & $\mathrm{P}$ & $41^{\circ} 53^{\prime} 52^{\prime \prime}$ & $15^{\circ} 19^{\prime} 43^{\prime \prime}$ & 19 & G \\
\hline PU094 & Acaya (LE) & $\mathrm{T}$ & $40^{\circ} 20^{\prime} 50^{\prime \prime}$ & $18^{\circ} 17^{\prime} 02^{\prime \prime}$ & 36 & $\mathrm{~S}$ \\
\hline PU095 & Rauccio 2 (LE) & $\mathrm{T}$ & $40^{\circ} 27^{\prime} 58^{\prime \prime}$ & $18^{\circ} 10^{\prime} 29^{\prime \prime}$ & 1,5 & $\mathrm{~S}$ \\
\hline PU096 & Casale Montalto (LE) & $\mathrm{T}$ & $40^{\circ} 08^{\prime} 35^{\prime \prime}$ & $18^{\circ} 17^{\prime} 39^{\prime \prime}$ & 86 & S \\
\hline PU097 & S. Elia (LE) & $\mathrm{T}$ & $40^{\circ} 04^{\prime} 59^{\prime \prime}$ & $18^{\circ} 15^{\prime} 22^{\prime \prime}$ & 83 & $\mathrm{~S}$ \\
\hline PU098 & Suriani 1 (LE) & $\mathrm{T}$ & $40^{\circ} 03^{\prime} 56^{\prime \prime}$ & $18^{\circ} 14^{\prime} 25^{\prime \prime}$ & 123 & $\mathrm{~S}$ \\
\hline PU099 & Suriani 2 (LE) & $\mathrm{T}$ & $40^{\circ} 04^{\prime} 28^{\prime \prime}$ & $18^{\circ} 14^{\prime} 15^{\prime \prime}$ & 117 & $\mathrm{~S}$ \\
\hline PU100 & Suriani 3 (LE) & $\mathrm{T}$ & $40^{\circ} 04^{\prime} 28^{\prime \prime}$ & $18^{\circ} 14^{\prime} 18^{\prime \prime}$ & 113 & $\mathrm{~S}$ \\
\hline PU101 & Suriani 4 (LE) & $\mathrm{T}$ & $40^{\circ} 04^{\prime} 32^{\prime \prime}$ & $18^{\circ} 14^{\prime} 11^{\prime \prime}$ & 107 & $\mathrm{~S}$ \\
\hline PU102 & Suriani 5 (LE) & $\mathrm{T}$ & $40^{\circ} 04^{\prime} 31^{\prime \prime}$ & $18^{\circ} 14^{\prime} 17^{\prime \prime}$ & 107 & S \\
\hline PU103 & Paduli 1 (LE) & $\mathrm{T}$ & $40^{\circ} 03^{\prime} 38^{\prime \prime}$ & $18^{\circ} 14^{\prime} 05^{\prime \prime}$ & 112 & $\mathrm{~S}$ \\
\hline PU104 & Paduli 2 (LE) & $\mathrm{T}$ & $40^{\circ} 03^{\prime} 34^{\prime \prime}$ & $18^{\circ} 14^{\prime} 08^{\prime \prime}$ & 112 & $\mathrm{~S}$ \\
\hline PU105 & Sombrino (LE) & $\mathrm{T}$ & $40^{\circ} 03^{\prime} 10^{\prime \prime}$ & $18^{\circ} 12^{\prime} 32^{\prime \prime}$ & 100 & $\mathrm{~S}$ \\
\hline PU106 & La Strea 1 (LE) & $\mathrm{T}$ & $40^{\circ} 14^{\prime} 24^{\prime \prime}$ & $17^{\circ} 54^{\prime} 24^{\prime \prime}$ & 0,5 & $\mathrm{~S}$ \\
\hline PU107 & La Strea 2 (LE) & $\mathrm{T}$ & $40^{\circ} 14^{\prime} 24^{\prime \prime}$ & $17^{\circ} 54^{\prime} 33^{\prime \prime}$ & 0,4 & $\mathrm{~S}$ \\
\hline PU108 & S.S. 175 (TA) & $\mathrm{T}$ & $40^{\circ} 27^{\prime} 57^{\prime \prime}$ & $16^{\circ} 44^{\prime} 44^{\prime \prime}$ & 25 & $\mathrm{C}$ \\
\hline PU109 & Torre Specchia1 (LE) & $\mathrm{T}$ & $40^{\circ} 18^{\prime} 33^{\prime \prime}$ & $18^{\circ} 22^{\prime} 29^{\prime \prime}$ & 4 & $\mathrm{~S}$ \\
\hline PU110 & Torre Specchia2 (LE) & $\mathrm{T}$ & $40^{\circ} 18^{\prime} 46^{\prime \prime}$ & $18^{\circ} 22^{\prime} 17^{\prime \prime}$ & 7 & $\mathrm{~S}$ \\
\hline PU111 & Palude di Cassano1 (LE) & $\mathrm{T}$ & $40^{\circ} 19^{\prime} 24^{\prime \prime}$ & $18^{\circ} 21^{\prime} 50^{\prime \prime}$ & 5 & $\mathrm{~S}$ \\
\hline PU112 & Palude di Cassano2 (LE) & $\mathrm{T}$ & $40^{\circ} 19^{\prime} 35^{\prime \prime}$ & $18^{\circ} 22^{\prime} 07^{\prime \prime}$ & 2 & $\mathrm{~S}$ \\
\hline PU113 & Cutrofianol (LE) & $\mathrm{P}$ & $40^{\circ} 05^{\prime} 58^{\prime \prime}$ & $18^{\circ} 11^{\prime} 60^{\prime \prime}$ & 95 & $\mathrm{~S}$ \\
\hline PU114 & Cutrofiano2 (LE) & $\mathrm{T}$ & $40^{\circ} 06^{\prime} 08^{\prime \prime}$ & $18^{\circ} 12^{\prime} 22^{\prime \prime}$ & 95 & $\mathrm{~S}$ \\
\hline PU115 & Cutrofiano3 (LE) & $\mathrm{T}$ & $40^{\circ} 05^{\prime} 59^{\prime \prime}$ & $18^{\circ} 12^{\prime} 25^{\prime \prime}$ & 93 & $\mathrm{~S}$ \\
\hline PU116 & Cutrofiano4 (LE) & $\mathrm{T}$ & $40^{\circ} 05^{\prime} 53^{\prime \prime}$ & $18^{\circ} 12^{\prime} 54^{\prime \prime}$ & 93 & $\mathrm{~S}$ \\
\hline PU117 & Collepasso (LE) & $\mathrm{T}$ & $40^{\circ} 04^{\prime} 22^{\prime \prime}$ & $18^{\circ} 12^{\prime} 22^{\prime \prime}$ & 121 & $\mathrm{~S}$ \\
\hline PU118 & Collepasso-Supersano (LE) & $\mathrm{T}$ & $40^{\circ} 03^{\prime} 49^{\prime \prime}$ & $18^{\circ} 13^{\prime} 04^{\prime \prime}$ & 112 & $\mathrm{~S}$ \\
\hline PU119 & Melissano (LE) & $\mathrm{T}$ & $39^{\circ} 59^{\prime} 08^{\prime \prime}$ & $18^{\circ} 07^{\prime} 00^{\prime \prime}$ & 49 & $\mathrm{~S}$ \\
\hline PU120 & Ugento1 (LE) & $\mathrm{P}$ & $39^{\circ} 55^{\prime} 55^{\prime \prime}$ & $18^{\circ} 11^{\prime} 00^{\prime \prime}$ & 94 & $\mathrm{~S}$ \\
\hline PU121 & Ugento2 (LE) & $\mathrm{P}$ & $39^{\circ} 54^{\prime} 29^{\prime \prime}$ & $18^{\circ} 10^{\prime} 57^{\prime \prime}$ & 116 & $\mathrm{~S}$ \\
\hline
\end{tabular}

Received: August 2010

Accepted: October 2010 